\title{
WORD SEARCH ULTIMATE GAME TOWARD STUDENT'S VOCABULARY MASTERY OF THE FIFTH GRADE STUDENTS AT MUHAMMADIYAH ELEMENTARY SCHOOL OF METRO
}

\author{
${ }^{1}$ Eva Faliyanti. Arif Irfan Tanjung ${ }^{2}$ \\ Muhammadiyah University of Metro, Lampung, Indonesia \\ 1.evafaliyanti1980@gmail.com \\ 2irfanarift@gmail.com
}

\begin{abstract}
One of the components in English that is very important in understanding when someone is communicating each other is vocabulary. The vocabulary is used to express the ideas. This research was aimed to find out the influence of using word search ultimate game in learning English for student's vocabulary mastery in the $5^{\text {th }}$ of Muhammadiyah Elementary School of Metro. The research was conducted by quantitative methods. The population of the research consisted of 235 students. The research divided into two groups, those are 24 students as the experimental group and 24 students as the control group, the total of the sample consist of 48 students. The research used cluster random sampling technique and an analysis by using t-test formula. The instruments of this research were pre-test and post-test. The result of analysis was indicated that the value of t obtained (6.961) was higher than that of table (2.06) at the significance level 0.05 and the significance $(0.000)$ was lower than 0.05). It means that there was significant influence toward student's vocabulary mastery using word search ultimate game of the fifth grade students of Muhammadiyah Elementary School of Metro.
\end{abstract}

Key Words: Vocabulary Mastery, Word Search Ultimate.

\section{INTRODUCTION}

In teaching-learning of English vocabulary is one of the components or sub skills that must be taught to learners. Richards and Willy (2002, p.4) claimed that a core component of language proficiency and provides many basic exercises for how well students speak, hear, read and write is vocabulary. It can be said that students will have difficulty mastering English skills when students have limited vocabulary. Even though students have studied up to university level, there must be other ways to enrich student's vocabulary mastery. Without adequate vocabulary, students cannot communicate effectively or express ideas because students think in words. 


\section{METHODOLOGY}

The design of this research is experimental research. It is an empirical study in which are studies exploit and controls one or more independent variables and observes the dependent variable (Munir, 2016, p.27). Therefore, the experimental research need a group that can be a control group and other group is experimental group. The population of this research was the student's in the $5^{\text {th }}$ grade of Muhammadiyah Elementary School of Metro in academic year 2019/2020. There were 7 class, those are Usman class consist of 34 students, Ali class consist of 32 students, Umar Class consist of 34, Abu Bakar consist of 34 students, Isa Class consist of 34 students, Yahya Class consist of 34 students and the last is Zakaria Class there were 35 students. Finally, the total numbers of population in this research are 235 students. The researcher chooses Yahya Class and Usman Class in the $5^{\text {th }}$ grade of Muhammadiyah Elementary School of Metro with 48 students as the sample to observe by using purposive sampling. Sampling is a way the researcher to select the number of individuals as a sample which presents the population. The research sample was selected by the cluster random technique. It was the sample selection in which all members of the population were naturally grouped in units (Wiersma and Jurs 2009, p.355). The researcher used random selection to determine which class will be the experimental group and the control group. The treatment in this research was visual media especially the game that related to English vocabulary, the researchers will teach vocabulary by using word search ultimate games as a media of teaching. The game helps the students easier to memorize vocabulary. It makes the students will be enthusiasm, enjoyable and interested in learning English. When teaching and learning process were hoped conducted by using word search ultimate games as media especially vocabulary was done, the students would be happy and they get new passion to learn English.

\section{FINDINGS}

The researcher is conducting the research on October 2019. Muhammadiyah Elementary School of Metro gave the schedule twice a week to the researcher, so there were two meeting in a week both of experimental and control group. In each meeting the researcher give three video about vocabulary mastery. The chart following is the data to comparing for experimental group and control group.

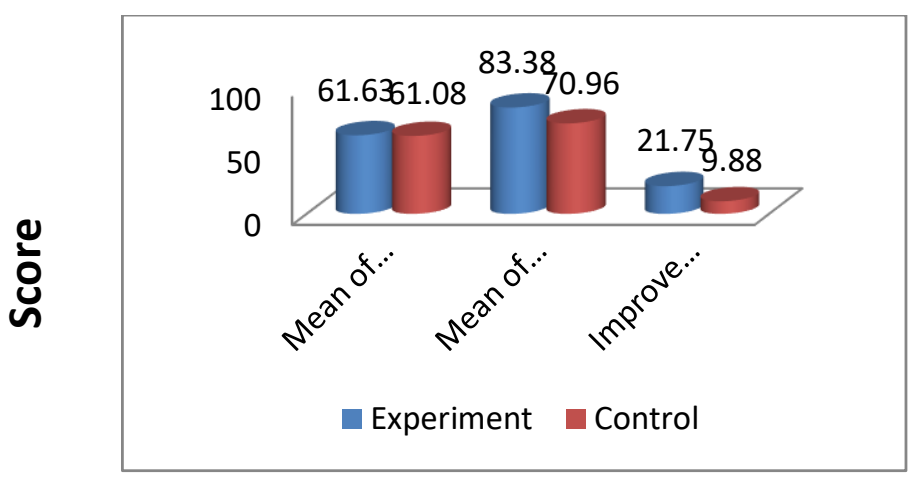


Then, to prove the hypothesis the researcher use t-test formula. Then, the criteria of testing the hypothesis were as follows: when the value of $t$ obtained is higher than that of t-table at the significant level of 0.05 , the hypothesis was accepted. In contrast, when the value of $t$ obtained is lower than that of t-table at the significant level of 0.05 , the hypothesis was rejected. The result of analysis as presented in Table 4.11 indicated that the value of $t$ obtained (6.961) was higher than that of table (2.06) at the significance level 0.05 and the significance (0.000) was lower than 0.05). That is why, the hypothesis was accepted. It means that teaching vocabulary using the Word Search Ultimate game at the $5^{\text {th }}$ grade of is effective and influence.

The result from the first previous research overview shows that $\mathrm{t}$-count $>\mathrm{t}$-table $(4.11>2.38)$ in the degree the significance was $1 \%$. It means that Ha was accepted and Ho was rejected. From the second previous research overview, the result shows that count 2 is bigger than table 1,671. It means that there were no significant different scores of students who are taught with and without a pictorial puzzle. The third previous research overview shows that there was significant effect on Hidden Word Game on the students' vocabulary. Based on the statistical test result by using t-test showed that t-table 1.99 and t-test 9.95 .

\section{CONCLUSION}

The measurement shows that increasing line of the vocabulary mastery of the experimental group was higher than the control group. The t-test measurement obtained was 6.961 , for $\alpha: 5 \%$ and the probability are 0.00 . The t-test table is 2.06 out of degree of freedom (df) 23. This means that the t-test was higher than the t-table $(6.962>2.06)$. It was found that the achievement of experimental group in vocabulary test was better than the control group. Therefore, it could be concluded that there is significant influence of usingword search ultimate gametoward the students' vocabulary mastery.

\section{REFERENCES}

Hatch, E., Brown, C. (2015). Vocabulary, Semantics, and Language Education. Cambridge: Cambridge University Press.

Heinich, R. (2002). Instructional Media and Technology for Learning, $7^{\text {th }}$ Edition. New Jersey: Prentice Hall, Inc.

Istianto, R. (2013). Improving Student's Vocabulary Mastery through Word Wall. Bandar Lampung: Lampung University.

Mc.Cafferty, S. G., Jacobs, G. M. (2006).Cooperative Learning and Second Language Teaching. Cambridge: Cambridge University Press. 
Munir, Fathul .(2016). The Effectiveness of Teaching Vocabulary by Using Cartoon Film toward Vocabulary Mastery of EFL Students. Tulungagung: IAIN Tulungagung, East Java.

Neuman, S. B., Dwyer, J. (2009). Missing in action: Vocabulary instruction in pre-k. UK: The Reading Teacher.

Read, John. (2000). Assessing vocabulary. Cambridge: Cambridge University Press.

Richards., Willy. 2002. Methodology in Language Teaching: An Anthology of Current Practice. Cambridge: Cambridge University.

Wiersma W., Jurs S.G.( 2009). Research Methods in Education an Introduction. New York: 